\title{
NUMBERED HEADS TOGETHER LEARNING STRATEGY FOR INCREASING FRESHMEN STUDENTS' ACHIEVEMENT IN LITERATURE THEORY COURSE
}

\author{
Fina Hiasa1; Emi Agustina²
}

Universitas Bengkulu1,2

Corresponding email: finahiasa@unib.ac.id

\begin{abstract}
This study aims to find out how the implementation of the Numbered Heads Together (NHT) learning strategy in Literature Theory courses improve the quality of learning. The subject of this research is the first semester students of Indonesian Language Education Study Program FKIP Unib who are taking Literature Theory courses. This study uses a descriptive method that produces a description of the extent of improving the quality of learning by using the Numbered Heads Together (NHT) learning strategy for students who become research samples. The application of the learning strategy in Literature Theory courses allows students to have active and meaningful involvement in learning activities both individually and in groups so that learning in Literature Theory courses becomes increasingly quality. Data collection techniques were carried out through questionnaires conducted in two cycles It also used a test technique in the form of an oral test in both cycles. Each cycle consists of four stages, namely (1) the planning stage (planning), (2) action (acting), (3) observation (observing), and (4) reflection (reflecting). In the first cycle the results obtained have not yet reached the required target. The required target is achieved in the second cycle. Learning outcomes in the second cycle showed that $37.5 \%$ of students have successfully achieved the required minimum passing score.
\end{abstract}

Keywords: Numbered Heads Together, Literary Theory

\section{INTRODUCTION}

Literary Theory is a compulsory subject for a Bachelor of Indonesian Language Education Study Program (PBI) Faculty of teacher training and education University of Bengkulu which has a weight of 3 credits. This course is given in odd semester (I) with the general learning achievement of students being able to apply simple literary theories to various types of literary works (poetry, prose, and drama). Through understanding literary theories, 
students are expected to have a basic foundation for advanced activities, namely analyzing literary works by applying literary theories that have been studied previously.

The achievement of this course is how students can simply apply various literary theories in analyzing literary works. This achievement encourages students to explore various types of literary theories in order to apply them to literary works. The theoretical style reflected in the literature theory course minimizes the contribution of students as students in teaching and learning activities so that the tendency that occurs is learning to be oneway with a dominant focus on lecturers. The result is teaching and learning activities tend to be monotonous and memorized type. Researchers have spread the initial questionnaire whose results indicate that the lack of motivation of students in studying literary theory.

Researchers hold discussions that produce reflections on the need for classroom action research by applying cooperative learning models that can maximize student learning outcomes. Slavin (2005, p.4) suggests that cooperative learning refers to a variety of teaching methods in which students work in small groups to help one another in learning subject matter. In implementing cooperative learning there are five elements that must be carried out in order to get maximum results as stated by (Lie, 2005), namely to achieve maximum results in Cooperative Learning, there are five elements of mutual learning models that must be applied, namely: (a) mutual positive dependence, (b) individual responsibility, (c) face to face, (d) communication between members, and (e) evaluation of group processes.

One model of cooperative learning is Numbered Heads Together (NHT). NHT type of cooperative learning is one type of cooperative learning that emphasizes specific structures that are designed to influence student interaction patterns and have a goal of increasing academic mastery. This type was developed by Kagen (in Ibrahim \& Nur, 2000) by involving students in studying the material included in a lesson and checking their understanding of the contents of the lesson. In addition, the Cooperative learning model Numbered Heads Together (NHT) is a learning model that emphasizes student activities in searching, processing and reporting information from various sources which are finally presented to the class (Rahayu, 2010).

Komalasari (2010, p.62) explains that NHT is a learning model where each student is numbered and made into groups which then randomly the teacher calls a number from the student. Furthermore Hamdayama (2014, p.177) stated that there are some advantages in applying the NHT learning model, namely a) to train students to be able to work together and respect the opinions of others b) to train students to become peer tutors, c) to foster a sense of togetherness, and d) to make students familiar with differences. 
Number Heads Together Learning Strategy for Increasing Freshmen Students'...

In the implementation of NHT there are several steps that are carried out as found by Kagen (cited in Tampubolon, 2014, p.94) namely a) students are divided into heterogeneous groups, and each student in each group gets a number b) Educators give assignments to each group (for each the group is the same, but for each student it is not the same as the student number, and for each student the same number gets the same assignment.) c) The group discusses the correct answer and makes sure each group member can do it. $d$ ) Educators call one of the student numbers to answer / report the results of their collaboration. e) Responses from other friends, then the educator points to another number (there is a class discussion). f) Individual quizzes and make progress scores for each student. g) Conclude and announce the results of the quiz and give rewards.

The cooperative learning model that is expected to improve the quality of Literature Theory lectures into something rational, cognitive, emotional, and affective for students is the Numbered Heads Together (NHT) learning model. Based on the previous explanation, it can be concluded that the steps in NHT learning are as follows (1) Students are divided into groups. Each student in each group gets a serial number, (2) The teacher gives an assignment and each group does it, (3) The group decides the answer that is considered the most correct and makes sure each group member knows this answer, (4) The teacher calls one of the student numbers with the number called reporting the results of their collaboration, (5) Responses from other groups (6) The Numbered Head Technique can also be continued to change the usual group composition and join with other students with the same number from other groups. The application of the Numbered Heads Together (NHT) learning model allows students to have active and meaningful involvement in learning activities both individually and in groups so that learning in Literature Theory courses becomes increasingly quality.

Research that is relevant to the research that researchers do is research conducted by Pratiwi (2013) in her thesis entitled Effectiveness of Using Numbered Heads Together to Improve Students' Ability to Understand Text Reading. The purpose of this study was to determine the effectiveness of the use of the NHT (Numbered Heads Together) method in understanding Japanese reading texts in the Shochukyu dokkai course. The conclusion obtained in this study is that the use of the Numbered Heads Together (NHT) method is effective in improving the ability of students to understand reading text in the shochukyu dokkai course. The difference between the research that the researcher will do with the above research is that this study will apply the NHT learning model to Literature Theory courses with the aim to improve the quality of learning to make it more fun and meaningful. Through the NHT learning model students are asked in groups to present a final report in an interesting form. The final report is not just a paper as usual but is in the form 
of a pocket book so that not only teamwork and communication skills are increasing, but also its creativity is developing. The application of the Numbered Heads Together (NHT) learning model enables students to have active and meaningful involvement in learning activities both individually and in groups so that learning in Literature Theory courses becomes more qualified.

\section{METHODS}

\section{Population and Research Samples}

The study population was all students of the Indonesian Language Study Program FKIP UNIB 2019/2020 academic year. Samples in this study were first semester students of Class B Indonesian Language Education Study Program FKIP UNIB who were taking Literature Theory courses.

\section{Instruments}

The research instrument is a tool used to collect research data. The instruments used were questionnaire sheets and pocket book assessment sheets and observation sheets when the NHT was applied. In addition, the instruments in this study are also questions that will be answered by students to find out student understanding.

\section{Data Analysis Procedures}

Data analysis techniques used in this study were descriptive statistics, calculating frequency, and percentages presented with tables and graphs. Categories in the data will be adjusted according to existing percentages. Following is the formula that will be used in data processing.

$$
X=\frac{€ X}{€ X m a k s} \times 100 \%
$$

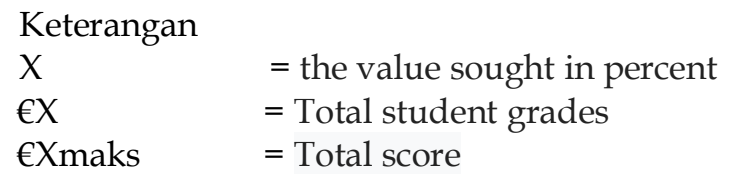

Table 1. Kategori Penilaian (Modifikasi Nurgiyantoro, 1988:363)

\begin{tabular}{clll}
\hline No & \multicolumn{2}{c}{ Percentage } & Category \\
\hline 1 & $80 \%-100 \%$ & Very good \\
2 & $70 \%-79 \%$ & Good & \\
3 & $60 \%-69 \%$ & Fair & \\
4 & $45 \%-59 \%$ & Bad & \\
5 & $0 \%-44 \%$ & Very bad & \\
\hline
\end{tabular}


Number Heads Together Learning Strategy for Increasing Freshmen Students'...

\section{FINDINGS}

Based on research conducted in August to October 2019 towards 40 PBI students with the aim to improve the quality of learning in semester I students of class B TA 2019/2020 in Literature Theory using the Numbered Heads Together (NHT) learning model, the following results were obtained:

Table 2. Acquisition of Values for Students Cycle one and two

\begin{tabular}{cccccccc}
\hline $\begin{array}{l}\text { Value } \\
\text { Range }\end{array}$ & Alphabet & Description & $\begin{array}{c}\text { Learning } \\
\text { achievement } \\
\text { target }\end{array}$ & $\begin{array}{c}\text { ACHIEVEMENT } \\
\text { OF CYCLE } \\
\text { VALUE I }\end{array}$ & $\begin{array}{c}\text { ACHIEVEMENT } \\
\text { OF CYCLE } \\
\text { VALUE II }\end{array}$ \\
\hline $90-100$ & A & Very good & $\mathbf{3 0} \%$ & 10 & $\mathbf{2 5 \%}$ & 15 & $\mathbf{3 7 , 5} \%$ \\
$80-89$ & $\mathrm{~B}$ & good & $\mathbf{5 0 \%}$ & 20 & $\mathbf{5 0 \%}$ & 20 & $\mathbf{5 0 \%}$ \\
$70-79$ & $\mathrm{C}$ & Pretty good & $\mathbf{2 0 \%}$ & 10 & $\mathbf{2 5 \%}$ & 5 & $\mathbf{1 2 , 5 \%}$ \\
$0-69$ & $\mathrm{D}$ & Not good & $\mathbf{0 \%}$ & 0 & $\mathbf{0} \%$ & 0 & $\mathbf{0} \%$ \\
& Jumlah & & $\mathbf{1 0 0}$ & 40 & $\mathbf{1 0 0}$ & 40 & $\mathbf{1 0 0}$ \\
\hline
\end{tabular}

From the table above it appears that the results of learning achievement in the first cycle are before the NHT learning model is applied and the second cycle after the NHT learning method is applied. From the table above it appears that an increase in learning outcomes in cycle II is the cycle in which the application of the NHT learning model is applied. Next will be explained in detail the learning process that occurs in cycle I and cycle II. This class action research plan will be carried out in two cycles, and each cycle consists of four stages, namely (1) planning, (2) acting, (3) observing, and (4) reflection (reflecting).

\section{Cycle 1}

After the material in the first cycle is complete, the lecturer gives an initial questionnaire to find out the student's initial knowledge of the literature theory courses. As a result, students' knowledge is still in the sufficient category which means it is not in accordance with the stated target. Below is a bar diagram illustrating the student's initial knowledge of Literature Theory courses in cycle I.

Tabel 3. Initial Conditions of Student Knowledge of Literature Theory

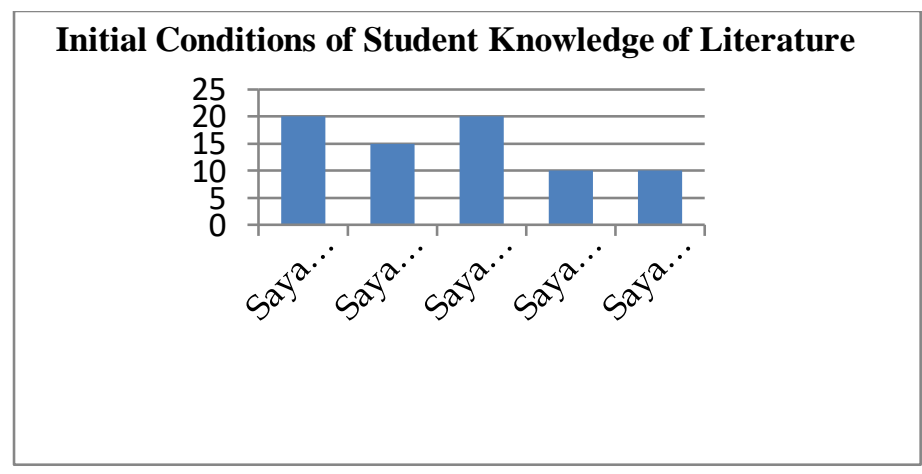


The bar chart above is the result of the questionnaire distribution conducted by the research team after learning in cycle I (before NHT was implemented). The result is that of 40 students, only 20 people know what literary theory is, what is the function of literary theory, and what types of literary works. As many as 10 out of 40 students know various literary theories and how to apply literary theories to literary works. These results indicate that the initial knowledge of students after learning in the first cycle is still not in accordance with the targets to be achieved.

The low percentage of students 'initial knowledge is also in line with the results of students' scores during the oral test in Cycle I. Oral tests are conducted after the implementation of group discussion learning with conventional models. Based on the student achievement table above, it appears that the learning outcomes before the NHT method has not been able to meet the expected performance targets in Literature Theory lectures.

From 40 students there are 10 students (25\%) who get an A. As many as 10 other students get the same percentage that is $25 \%$ for a grade $C$. The remaining 20 people (50\%) get a $B$ grade and for a $D$ grade are 0 people $(0 \%)$. The target of learning achievement or completeness is A by $30 \%, \mathrm{~B}$ by $50 \%, \mathrm{C}$ by $20 \%$, and D $0 \%$. Learning outcomes in the first cycle using the conventional method shows that the achievement target has not been reached, therefore this study continues to the second cycle by applying the NHT learning model with the expectation that learning outcomes increase.

\section{Cycle 2}

In the planning phase of the second cycle preparations for the learning tools needed during the teaching and learning process, include: (1) preparing Literature Theory courses, (2) preparing material in the form of power points, (3) preparing questionnaires and assessment sheets in the implementation of the model learning Numbered Heads Together (NHT) as a guide in research action. Berikut adalah tabel Lembar Pedoman Model Pembelajaran Kolaboratif Tipe NHT.

Table 4. The NHT Type Collaborative Learning Guideline Sheet for Cycle II

* adapted from Endah and Eviliyanto (Journal of Education, Vol. 15, No. 1, June 2017

STAGES LEARNING PROCESS
Phase 1 Determine the topic and organize
students into groups

1. Students join their groups. 2. Every student has a certain number that melakat on themselves. 3. Each group gets 1 topic to be discussed

Phase-2 each group

The group has a discussion

a. Looking for information from various sources.

b. Compare and evaluate the relevance of sources. 


\section{STAGES}

Phase 3

The group prepares a final report and plans a presentation

Phase 4

The group made a presentation

Phase -5

Evaluating

\section{LEARNING PROCESS}

c. Explain, expand, and filter knowledge, and make information.

d. Formulate answers to questions.

1. Determine the main ideas of existing friends.

2. Explain, compare, evaluate findings.

3. Relating findings to common problems.

4. Decide on the most appropriate explanation to be presented and ensure each group member knows the results 1 . The lecturer calls a certain number from the group discussing a particular topic. 2 . other groups respond to the explanation 3 . Students with the same number from different groups join one group and exchange information about topics that have been mastered in the initial group. 1. Evaluate the ideas of research results. 2. Evaluate knowledge. 3. Combining all group findings. 4. Demonstrate achievements as researchers and as group members.

The results of the implementation of NHT in the second cycle showed an increase in that of the 40 students there were 15 students $(37.5 \%)$ who received an A. As many as 20 students with a B grade (50\%). The rest is a $\mathrm{C}$ value of 5 people $(12.5 \%)$ and a $\mathrm{D}$ value of 0 people $(0 \%)$. These results exceed the achievement target which means that the application of NHT in cycle II in Literature Theory courses has improved learning outcomes. This is also in line with the increase in the final knowledge of students who have completed the final questionnaire illustrated through the diagram below.

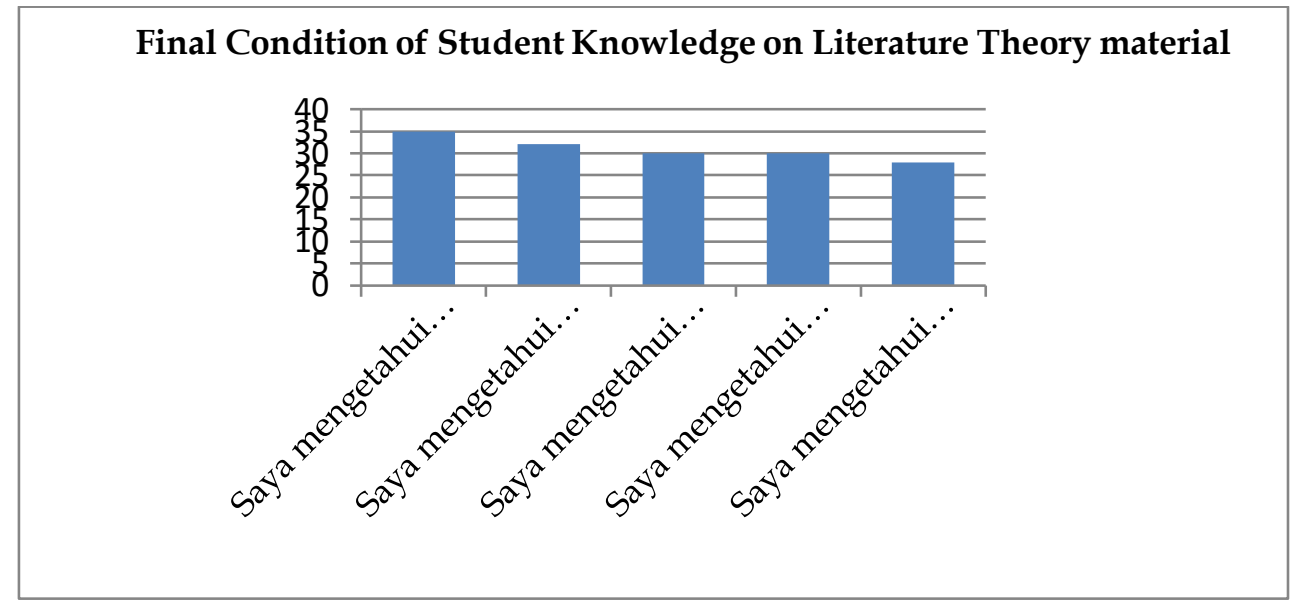


The research team distributed questionnaires to find out the knowledge of students after the NHT was applied, the results of which were 40 students, there were 35 people who knew what literary theory was, 32 what was the function of literary theory, and 30 people who knew what types of literary works. As many as 30 people from 28 students know various types of literary theories and how the application of literary theories to literary works. These results indicate that the final knowledge of students after learning in cycle II (after the implementation of the NHT) can be said to be increased.

\section{DISCUSSION}

The difference between the research that the researcher will do with the above research is that this study will apply the NHT learning strategy to Literature Theory courses with the aim to improve the quality of learning to make it more fun and meaningful. Through the NHT learning model students are asked in groups to present a final report in an interesting form. The final report is not just a paper as usual but is in the form of a pocket book so that not only teamwork and communication skills are increasing, but also the power of creativity is developing. One such study with the research that the researchers conducted was a study by Pratiwi (2013) in her thesis entitled Effectiveness of Using Numbered Heads Together to Improve Students' Ability to Understand Text Reading. The results of the study show that the use of the Numbered Heads Together (NHT) method is effective in improving students' ability to understand reading texts in the shochukyu dokkai course. A very clear difference can be seen from the research subjects used, other than that previous research is more specific to one activity, namely reading activities. The research conducted by this researcher requires students to learn comprehensively so as to make students have active participation and roles in learning activities both individually and in groups that make learning activities in Literature Theory courses more qualified.

Based on research conducted in August to October 2019 of 40 PBI students with the aim to improve the quality of learning in semester I students of class B TA 2019/2020 on Literature Theory courses using the Numbered Heads Together (NHT) learning model, the result is that NHT opinion can improve student learning outcomes. This achievement was achieved in cycle II. The results of learning in the first cycle showed that of 40 students there were 10 students $(25 \%)$ who got an A. As many as 10 other students got the same percentage of $25 \%$ for a grade $C$. The remaining 20 people $(50 \%)$ got a grade $\mathrm{B}$ and for $\mathrm{D}$ values of 0 people $(0 \%)$. The target of learning achievement or completeness is A by $30 \%$, B by $50 \%, \mathrm{C}$ by $20 \%$, and D $0 \%$. Learning outcomes in the first cycle using the conventional method shows that the achievement target has not been reached, so this study continues to the second 
Number Heads Together Learning Strategy for Increasing Freshmen Students'...

cycle by applying the NHT learning model with the expectation that learning outcomes increase.

Learning outcomes in the second cycle showed that of 40 students there were 15 students (37.5\%) who received an A. As many as 20 students with B $(50 \%)$. The rest is a $C$ value of 5 people $(12.5 \%)$ and a $D$ value of 0 people $(0 \%)$. These results exceed the achievement target which means that the application of NHT in cycle II in Literature Theory courses has improved learning outcomes. The conclusion is the application of NHT in Literature Theory courses in PBI Unib students in semester I of class B TA 2019/2020 can improve learning outcomes.

\section{CONCLUSION AND SUGGESTION}

From the results of the research that has been done, it can be concluded in the following. First, the application of the Numbered Heads Together (NHT) learning model for Literature Theory courses in PBI Unib students in semester I of class B TA 2019/2020 can improve student learning outcomes. Mastery learning can be obtained in cycle two of the two planned cycles. Second, this improvement in learning outcomes shows that the Numbered Heads Together (NHT) model is considered an effective way to improve student learning outcomes. For further research, it is expected that in applying the Numbered Heads Together (NHT) learning model, it is expected that lecturers apply to different subjects. Lecturers can use different learning models to be applied to literary theory courses and other literary courses.

\section{REFERENCES}

Hamdayama, J. (2014). Model dan metode pembelajaran kreatif dan berkarakter. In Bogor: Ghalia Indonesia.

Ibrahim, M., \& Nur, M. (2000). Pembelajaran kooperatif. Surabaya: University Press.

Komalasari, K. (2010). Pembelajaran kontekstual konsep dan aplikasi. In Bandung: Refika Aditama.

Lie, A. (2005). Cooperating learning: mempraktikkan cooperative learning di ruang-ruang kelas (Vol. 7386). In Jakarta: Gramedia.

Pratiwi, I. S. (2013). EFEKTIVITAS PENGGUNAAN METODE NHT (NUMBERED HEADS TOGETHER) UNTUK MENINGKATKAN KEMAMPUAN MAHASISWA DALAM PEMAHAMAN MEMBACA TEKS. Universitas Negeri Semarang.

Rahayu, S. P. (2010). Deskripsi Sikap Siswa Terhadap Lingkungan Melalui Pendekatan Pengungkapan Nilai (Values Clarification Approach) Pada Kelas VII MTs Guppi Natar. In Skripsi. Bandar Lampung: Universitas Lampung.

Slavin, R. E. (2005). Cooperative learning teori, riset dan praktik. In Bandung: 
Fina Hiasa; Emi Agustina

Nusa Media (Vol. 236).

Tampubolon, S. (2014). Penelitian Tindakan Kelas Sebagai Pengembangan Profesi Pendidik dan Keilmuan. Erlangga. 